\title{
Urban Vegetative Cover Fragmentation in the U.S.
}

Associations with Physical Activity and BMI

Wei-Lun Tsai, PhD, ${ }^{1}$ Myron F. Floyd, PhD,${ }^{1}$ Yu-Fai Leung, PhD,${ }^{1}$ Melissa R. McHale, PhD,${ }^{2}$

Brian J. Reich, $\mathrm{PhD}^{3}$

From the ${ }^{1}$ Department of Parks, Recreation and Tourism Management, North Carolina State University, Raleigh, North Carolina; ${ }^{2}$ Department of Forestry and Environmental Resources,

North Carolina State University, Raleigh, North Carolina; and ${ }^{3}$ Department of Statistics, North Carolina State University, Raleigh, North Carolina

Address correspondence to: Wei-Lun Tsai, PhD, 2820 Faucette Drive, Box 8004, Biltmore Hall, North Carolina State University, Raleigh NC 27695-8004. E-mail: wtsai@ ncsu.edu. 
Introduction: Urban vegetative cover provides a range of ecosystem services including contributions to human health and well-being. Urbanization exerts tremendous pressure on this natural resource, causing fragmentation and loss of urban greenspace. This study aimed to examine associations between vegetative cover fragmentation and physical activity and BMI at the county scale in the U.S. metropolitan statistical areas greater than 1 million in population. Methods: National Land Cover Database 2006 and Behavioral Risk Factor Surveillance System 2008 provided land cover and human health data, respectively. Analyses were performed in 2013 at the county scale where the health data were reported. Spearman rank correlation and stepwise and hierarchical regression models were applied to estimate relationships between land cover and health variables.

Results: After controlling for median household income and race, greater forest edge density $(\beta=0.272, p<0.05)$ and larger size of herbaceous patches $(\beta=0.261, p<0.01)$ were associated with higher percentage of participation in physical activity within counties. More connections between forest and developed area $(\beta=0.37, p<0.01)$ and greater edge density of shrubland $(\beta=0.646, p<0.001)$ were positively associated with higher percentage of normal BMI $(<25$ $\mathrm{kg} / \mathrm{m}^{2}$ ) within counties.

Conclusions: Forest land cover and some degree of fragmentation are associated with population physical activity. Future studies should examine how built environments and varying land cover configurations influence physical activity and weight status. 


\section{Introduction}

Physical inactivity and obesity remain important public health challenges. In the U.S. and many industrialized countries, most adults do not accumulate sufficient physical activity, increasing their risk for overweight, cardiovascular diseases, some forms of cancers, reduced bone strength, and mental disorders. ${ }^{1,2}$ Public parks and greenspace have become more prominent among environmental and policy strategies to increase physical activity and prevent obesity. ${ }^{3}$ Thus, loss or significant alteration of urban greenspace can have important consequences for public health. More than $80 \%$ of the U.S. population lives in urban areas. Between 2000 and 2010, the urban population in the U.S. grew by $12.1 \%$, ahead of overall population growth of $9.7 \% .{ }^{4}$ Because of expanding urbanization, tremendous pressure is exerted on natural ecosystems, leading to landscape fragmentation and loss of greenspace and open space available for outdoor recreation and physical activity. ${ }^{5,6}$ It is imperative to understand relationships of urbanization and urban vegetation fragmentation on public health as more of the world's population lives in urbanized areas.

Multiple studies document how parks and public greenspace support recreation and physical activity among adults and children. ${ }^{7-10}$ Natural features such as trees, water, ${ }^{11}$ greenspace in neighborhoods, ${ }^{12,13}$ and greenness along greenway trails ${ }^{14}$ are associated with greater use ${ }^{15}$ or enhanced enjoyment of such resources. Longitudinal evidence suggests that urban greenspace has also been linked to weight status among children,${ }^{16}$ although the findings may be restricted in highly populated areas. ${ }^{17}$ Adjusting for SES covariates, Lovasi et al. ${ }^{18}$ observed that higher street tree density was associated with a $12 \%$ lower prevalence of obesity among children (aged 3-5 years) in New York City. By contrast, Potestio and colleagues ${ }^{19}$ found marginal or no significant associations between several objective measures of greenspace in Calgary and children's weight 
status after adjusting for SES. Among adults, lower BMI has been observed in high greenspace (measured by normalized difference vegetation index) neighborhoods with more destinations for walking than in less green neighborhoods. ${ }^{20}$ Ellaway et al. ${ }^{21}$ used trained auditors to obtain measures of local vegetation in eight European cities. This study found that residents of areas with a high greenery level were significantly less likely to be overweight or obese (measured by $\mathrm{BMI})$.

Although evidence on contributions of urban natural greenspace to physical activity and healthy weight status is accumulating, opportunities exist to extend the literature in significant ways. First, most studies involving greenspace and physical activity and obesity are conducted at the park or neighborhood scale. Research at larger geographic scales (e.g., county, cities, and metropolitan areas) may be more appropriate for informing land use planning for larger areas. ${ }^{22}$ In addition, the focus on parks and other public greenspace excludes other green environments (e.g., private lands) that can support outdoor activities. ${ }^{22}$ Analyses at larger scales and inclusion of public and private lands follow current practice related to green infrastructure and land use planning. In particular, focusing on green infrastructure and natural ecosystems can provide information on dynamic natural ecological networks on which parks and open space depend. ${ }^{23,24}$ Lastly, how changes in greenspace composition and structure associated with increasing urbanization relate to physical activity and weight status have not been considered. This study examines associations between the fragmented characteristics of urban vegetative cover and physical activity and weight status controlling for socioeconomic factors in counties in U.S. metropolitan statistical areas (MSAs) greater than 1 million in population. 
Vegetative cover fragmentation describes the change in forest composition and configuration through the process of urbanization. ${ }^{25-27}$ Fragmentation can be characterized as number and density of fragments or patches; connectivity of patches; and their accessibility, cohesion, and distance between them. ${ }^{28-33}$ Although fragmentation of urban ecosystems has been shown to have negative impacts on natural ecological systems (e.g., disruption of wildlife habitat), its potential effects on physical activity and weight status have not been explored. Prior research suggests greater extent of vegetative cover is likely related to physical activity and weight status, as it constitutes green infrastructure essential for activity spaces such as parks and trails. Findings from studies on urban sprawl lead to an expectation that increasing fragmentation will be negatively related to physical activity and positively related to weight status. ${ }^{34}$ Finally, the authors expect that different configurations of fragmentation will have different relationships to physical activity and weight status. To summarize, this study addresses the following hypotheses:

1. Higher total vegetative cover will be positively related to physical activity and negatively related to weight status $\left(\mathrm{BMI}<25 \mathrm{~kg} / \mathrm{m}^{2}\right)$.

2. More-fragmented vegetative cover will be negatively related to physical activity and positively related to weight status.

3. Different measures of fragmentation will have different relationships with physical activity and weight status.

\section{Methods}

Data were obtained for U.S. metropolitan statistical area with population $>1$ million $(\mathrm{N}=52)$ to focus on the largest MSAs in the country. ${ }^{22,35}$ Relationships were analyzed at the county level. 
Although 421 counties comprised the 52 MSAs, both health data and land cover data were only available for 135 counties (Figure 1).

\section{Measures}

The Selected Metropolitan/Micropolitan Area Risk Trends from 2008 derived from the Behavioral Risk Factor Surveillance System provided data for physical activity and BMI. The data set provides annual local area estimates for counties and MSAs. However, 286 of 421 counties did not have the estimates for this study owing to small sample sizes. Physical activity was based on self-reported measures of respondent participation in any physical activity other than regular work in the past month, including any duration and intensity. BMI was a calculated variable derived from self-reported body weight and height. For the analysis, physical activity was measured as the percentage of residents within the county indicating participation in physical activity other than work. BMI was measured as the percentage with BMI $<25 \mathrm{~kg} / \mathrm{m}^{2}$, indicating normal BMI.

The definition of "vegetative cover" includes greenspaces and areas with green elements. The National Land Cover Database (NLCD) 2006 provided data on vegetative cover. The NLCD provides complete land cover data for the coterminous U.S. from Landsat Thematic Mapper at 30-meter resolution. ${ }^{36}$ The NLCD Level I classification includes eight types: forest, shrubland, herbaceous, planted/cultivated, barren, developed area, water, and wetlands. The NCLD has been a data source for previous research on health and greenspace. ${ }^{37}$ Of primary interest in this study were vegetative covers, including forest, shrubland, and herbaceous types. Forest refers to areas with woody vegetation (including deciduous, evergreen, and mixed forests) >6 meters in height; shrubland is defined as areas with woody vegetation (including shrubs in early successional stage 
or trees stunted by weather conditions) and young trees <6 meters; and herbaceous refers to areas with grassland or herbaceous vegetation (e.g., grasses, wildflowers). Accuracy for the NLCD Level I is $84 \% .^{38}$

Several metrics are commonly used to measure degree of land cover fragmentation representing landscape composition and configuration, relative differences among land cover patches, and the degrees of aggregation or clumping of patch types. ${ }^{39,40}$ Seven land cover metrics, including percentage of green land cover, patch area, patch density, edge density, edge contrast index, Euclidean distance, and patch cohesion index, were selected based on the major characteristics of urban forest fragmentation and potential influence on ecosystem and human health. ${ }^{8,28-33,41-44}$

These seven landscape metrics are categorized into three domains:

1. area-edge, landscape composition, and the simplest configuration;

2. contrast, the relative distance among patch types; and

3. aggregation or the degree of clumping of patch types. ${ }^{45}$

The specific metrics for each domain are described in Table 1. Area-edge metrics reflect the availability of vegetative covers. The authors expected that greater abundance would correlate with greater physical activity and normal BMI. Contrast measures reflect possibility of movement between patch types (e.g., residential areas and vegetative covers) that potentially provide more access for physical activity. Conversely, greater aggregation or clumping of patch types could increase difficulty of access for activity. Greater patch density can increase opportunity for people to contact with vegetative covers, as urban vegetation fragmentation breaks up large patches into many small patches. In the absence of prior theory and evidence, 
differences are expected in how each metric associates with physical activity and BMI. Higher values of patch density, edge density, edge contrast, and Euclidean distance indicate more fragmentation; conversely, higher values for percentage of land cover, patch area, and cohesion indicate less fragmentation. All fragmentation metrics were generated in 2013 using FRAGSTATS, version 4.2, a spatial pattern analysis program designed to compute a variety of landscape metrics. ${ }^{45}$

Total population, total housing units, median household income, and percentage black/African American population for each county were obtained from the American FactFinder, U.S. Census Bureau and were treated as possible confounding variables. ${ }^{46}$ Population and housing density served as proxy indicators for built environment ${ }^{47,48}$ and were calculated using the total population and housing units divided by the total land area of the county, respectively, using $\operatorname{ArcGIS}^{\circledR}$, version 10.

\section{Statistical Analysis}

Analyses were conducted from August to December 2013 using SPSS, version 19 and R, version

2.14.1. Bivariate and multivariate relationships among vegetative cover and physical activity and BMI were examined by Spearman's rank correlation and regression models, respectively.

Regression models included stepwise and hierarchical regressions. Stepwise regression was used first to find the best-fit model for predicting physical activity and BMI using the Akaike Information Criterion ${ }^{49}$ as the selection criterion. Subsequently, hierarchical regression was used to test the best-fit models with potential confounders and the variance inflation factor was used to adjust the models for potential multicollinearity. Hierarchical models are appropriate for 
estimating associations between land cover variables and the outcomes while controlling for potential confounders. ${ }^{50}$

\section{Results}

The percentage of county residents participating in non-work physical activity ranged from $65.1 \%$ to $90.2 \%$ with a mean of $77.06 \%(\mathrm{SD}=4.92)$. The percentage of normal BMI ranged from $24.1 \%$ to $55.5 \%$ with a mean of $38.02 \%$ ( $\mathrm{SD}=5.42$ ). Forest, shrubland, and herbaceous vegetation at the national scale accounted for $42.79 \%$ of all land cover. Developed area was the highest percentage among all land cover types at $30.47 \%$. Seven fragmentation metrics were generated for vegetative covers. Mean patch area for vegetative covers ranged from $3.5 \mathrm{~m}^{2}$ (herbaceous) to $17.46 \mathrm{~m}^{2}$ (forest). Mean patch density ranged from 0.77 patches per 100 ha (herbaceous) to 1.53 patches per 100 ha (forest). Mean edge density ranged from $10.53 \mathrm{~m} / \mathrm{ha}$ (herbaceous) to $41.62 \mathrm{~m} / \mathrm{ha}$ (forest). Mean edge contrast index ranged from $20.32 \%$ (shrubland) to $44.41 \%$ (forest). Mean Euclidean distance ranged from $211.62 \mathrm{~m}$ (forest) to $673.50 \mathrm{~m}$ (herbaceous). Mean patch cohesion index ranged from $83.96 \%$ (herbaceous) to $95.91 \%$ (forest). Mean population density was $1,087.70$ per $\mathrm{km}^{2}(\mathrm{SD}=2,751.05)$, mean housing density was $482.55 \mathrm{~km}^{2}(\mathrm{SD}=1,373.29)$, mean median household income was U.S. \$63,035.12 $(\mathrm{SD}=15,900.59)$, and mean percentage of black/African American population was $15.89 \%$ $(\mathrm{SD}=14.15)$.

Bivariate and multivariate relationships (Tables 2 and 3) among vegetative cover and physical activity and obesity were examined. Only physical activity correlated significantly with vegetative cover. All three vegetative covers (forest, shrubland, and herbaceous) were 
significantly and positively correlated with physical activity. Patch density of herbaceous vegetation exhibited the strongest correlation with physical activity $(\rho=0.35, p<0.001)$. In multivariate relationships, when adjusting for all other variables, edge density of forest type $(\beta=0.272, p<0.05)$ and larger size of herbaceous patches $(\beta=0.261, \mathrm{p}<0.01)$ were significant predictors of physical activity. The model explained $35.3 \%$ of the variance in physical activity prevalence in the study counties.

There were no significant bivariate correlations between vegetative cover and normal BMI. Yet, the multivariate BMI model explained $33.5 \%$ of the variance in BMI adjusting for potential confounders. More connections between forest type and developed area $(\beta=0.37, p<0.01)$, greater edge density of shrubland type $(\beta=0.646, p<0.001)$, and larger size of herbaceous patches $(\beta=0.332, p<0.01)$ were associated with a greater proportion of normal BMI. Higher patch density of shrubland type $(\beta=-0.504, p<0.01)$ was associated with lower proportion of normal BMI.

\section{Discussion}

Urban vegetative cover provides critical ecosystem services important for public health. Consistent with expectations, this study's results showed that more physical activity tended to be associated with greater amounts of vegetative cover at the county scale based on bivariate analyses. These findings align with previous studies that found positive associations between urban greenspace and physical activity. ${ }^{12,51}$ In addition, multivariate analyses showed results consistent with reports that demonstrate the importance of accessibility ${ }^{8,42,52}$ and size $e^{53,54}$ for use of parks, park-based physical activity, and walking. ${ }^{53}$ The results differ from European studies in 
which significant associations were not observed between greenspaces and levels of physical activity. ${ }^{51,55,56}$ Overall, findings are in agreement with studies showing that greenspace is positively related to overall health. ${ }^{57}$

Findings involving land cover fragmentation ran counter to the study hypotheses, specifically the expected negative correlation with physical activity. Urban vegetative cover is typically fragmented by residential and commercial development, leading to the reduction of patch size and increases of patch density and edge density..$^{29,30,33}$ Research on urban forest fragmentation has found negative impacts on ecosystem structure and function such as disruption of wildlife habitat and introduction of invasive species. ${ }^{58}$ The present analyses suggest that edge fragmentation within counties may be beneficial for physical activity possibly because more access and opportunities are created for people to enjoy natural greenspaces for recreation. Landscape preference studies have shown that recreationists prefer forest recreation settings with edge-like characteristics. ${ }^{44,59-61}$ Consistent with past research, bivariate results showed forest patch density was positively associated with physical activity, suggesting that more greenspace parcels provide more opportunities for people to engage in physical activity. ${ }^{8}$ However, the results from the multivariate analysis showed that patch density of shrubland was negatively associated with normal BMI. This may indicate that this vegetative type among other land cover types is less conducive for promoting healthy weight at the population level.

In view of the large body of literature linking greenspace and health, this study contributes by showing that type of vegetative cover in addition to its ecological character are important in understanding how greenspace is related to health outcomes. For example, forest patches with 
greater edge were associated with greater prevalence of activity and greater shrubland edge density associated with positively physical activity and normal BMI. Such findings can inform ongoing attempts to assess what types, configuration, and amount of greenspaces are needed to achieve public health goals.

Findings from this study can encourage theorizing on mechanisms by which vegetative cover and fragmentation relate to physical activity. Mass and colleagues ${ }^{51}$ suggest that certain configurations of different land cover types and fragmentation patterns may create suitable infrastructure for outdoor recreation settings that can support activity. In addition, fragmentation pattern effects on ecosystem services could exert influence through other ecological factors including bird species richness, which could be linked to psychological benefits of greenspace. ${ }^{62}$

\section{Limitations}

Several limitations should be acknowledged. First, the cross-sectional study design did not allow for analysis of temporal effects or causality with respect to land cover change and health outcomes. Moreover, owing to self-selection (that people choose where they live and are not randomly assigned), it may be that populations inclined to be physically active tend to live in areas with certain land cover patterns. Land use patterns could also reflect the preferences of populations supportive of environmental policies that promote active living. Future studies should take advantage of time series data to examine how changes in land cover influence population physical activity and weight status. Second, the health data used in the analysis were based on self-report measures using dichotomous coding and aggregated to the county level, which often lead to certain biases (e.g., construct validity). ${ }^{63}$ As a result, objective measures of physical activity (e.g., measured by accelerometer) and BMI (calculated from measured height 
and weight) were not used. However, previous studies have reported acceptable reliability and validity of BRFSS physical activity measures. ${ }^{64,65}$ The present study did not analyze intensity or extent of habitual activity. In view of past uses of the BRFSS, a single-item measure is adequate for classifying respondents into active and inactive groups for this study ${ }^{64}$ Furthermore, not all the counties within a MSA have a measure because of small sample size. A third limitation relates to the quality of land cover data. Analyses relied on land cover data captured at 30-meter resolution. Data from higher spatial resolution (e.g., 10-meter or less) may be more effective in providing greater detail in land cover. Related to this, it would also be important to capture health data at similar scales (e.g., block or postal ZIP code level). Fourth, the analyses did not control for additional built environment variables (e.g., sidewalks, trails, etc.) known to associate with physical activity, as well as potential land uses for future recreational uses (e.g., grayfields and brownfields). ${ }^{66}$ Finally, in view of potential ecological fallacy biases, the authors caution readers to recognize that the findings address county-level prevalence and associations and not individual behaviors.

\section{Conclusions}

Strengths of this study included the detailed characterization of urban vegetative cover and its associations with physical activity and BMI for the U.S. largest metropolitan areas. Second, the study examined vegetative cover within the broader context of green infrastructure and ecological networks more suitable for regional land use planning. ${ }^{67,68}$ Building on previous research, ${ }^{37}$ this study provides an example of how to integrate land cover and health surveillance data (e.g., BFRSS) to explore associations between vegetative cover and public health. Further studies are needed to identify and evaluate how specific land cover metrics influence health, explore optimal configurations of land cover types for desired health outcomes, and increase 
understanding how policy processes can be used to achieve optimal configurations for health in urban areas. 


\section{Acknowledgments}

This research was funded in part by a grant from the National Urban and Community Forestry Advisory Council, U.S. Department of Agriculture Forest Service. Views expressed in the manuscript are solely those of the authors.

No financial disclosures were reported by the authors of this paper. 


\section{References}

1. Goodwin PJ, Stambolic V. Impact of the obesity epidemic on cancer. Annu Rev Med. 2015;66(1):281-296. http://dx.doi.org/10.1146/annurev-med-051613-012328.

2. Friedenreich CM, Orenstein MR. Physical activity and cancer prevention: Etiologic evidence and biological mechanisms. J Nutr. 2002;132(11):3456S-3464S.

3. Hunter RF, Christian H, Veitch J, Astell-Burt T, Hipp JA, Schipperijn J. The impact of interventions to promote physical activity in urban green space: A systematic review and recommendations for future research. Soc Sci Med. 2015;124:246-256. http://dx.doi.org/10.1016/j.socscimed.2014.11.051.

4. U.S. Census Bureau. Growth in urban population outpaces rest of nation, Census Bureau reports. 2012.

5. McDonald RI, Forman RTT, Kareiva P. Open space loss and land inequality in United States cities. Plos One. 2010;5(3):9509. http://dx.doi.org/10.1371/journal.pone.0009509.

6. Hug S-M, Hartig T, Hansmann R, Seeland K, Hornung R. Restorative qualities of indoor and outdoor exercise settings as predictors of exercise frequency. Health Place. 2009;15(4):971-980. http://dx.doi.org/10.1016/j.healthplace.2009.03.002.

7. Roemmich JN, Epstein LH, Raja S, Yin L, Robinson J, Winiewicz D. Association of access to parks and recreational facilities with the physical activity of young children. Prev Med. 2006;43(6):437-441. http://dx.doi.org/10.1016/j.ypmed.2006.07.007.

8. Cohen DA, McKenzie TL, Sehgal A, Williamson S, Golinelli D, Lurie N. Contribution of public parks to physical activity. Am J Public Health. 2007;97(3):509-514. http://dx.doi.org/10.2105/AJPH.2005.072447. 
9. Floyd MF, Spengler JO, Maddock JE, Gobster PH, Suau LJ. Park-based physical activity in diverse communities of two U.S. cities: An observational study. Am J Prev Med. 2008;34(4):299-305. http://dx.doi.org/10.1016/j.amepre.2008.01.009.

10. Besenyi GM, Kaczynski AT, Wilhelm Stanis SA, Vaughan KB. Demographic variations in observed energy expenditure across park activity areas. Prev Med. 2013;56(1):79-81. http://dx.doi.org/10.1016/j.ypmed.2012.10.011.

11. Tinsley HEA, Tinsley DJ, Croskeys CE. Park usage, social milieu, and psychosocial benefits of park use reported by older urban park users from four ethnic groups. Leis Sci. 2002;24(2):199-218. http://dx.doi.org/10.1080/01490400252900158.

12. Sugiyama T, Leslie E, Giles-Corti B, Owen N. Associations of neighbourhood greenness with physical and mental health: do walking, social coherence and local social interaction explain the relationships? J Epidemiol Community Health. 2008;62(5):9. http://dx.doi.org/10.1136/jech.2007.064287.

13. Fisher KJ, Li F, Michael Y, Cleveland M. Neighborhood-level influences on physical activity among older adults: a multilevel analysis. J Aging Phys Act. 2004;12(1):45-63.

14. Lindsey G, Wilson J, Anne Yang J, Alexa C. Urban greenways, trail characteristics and trail use: Implications for design. Journal of Urban Design. 2008;13(1):53-79. http://dx.doi.org/10.1080/13574800701804033.

15. Reynolds KD, Wolch J, Byrne J, et al. Trail characteristics as correlates of urban trail use. Am J Health Promot. 2007;21(4 Suppl):335-345. http://dx.doi.org/10.4278/0890-117121.4s.335. 
16. Bell JF, Wilson JS, Liu GC. Neighborhood greenness and 2-Year changes in body mass index of children and youth. Am J Prev Med. 2008;35(6):547-553. http://dx.doi.org/10.1016/j.amepre.2008.07.006.

17. Liu G, Wilson J, Qi R, Yin J. Green neighbourhoods, food retail and childhood overweight: differences by population density. Am J Health Promot. 2007;21:317-325. http://dx.doi.org/10.4278/0890-1171-21.4s.317.

18. Lovasi GS, Schwartz-Soicher O, Quinn JW, et al. Neighborhood safety and green space as predictors of obesity among preschool children from low-income families in New York City. Prev Med. 2013;57(3):189-193. http://dx.doi.org/10.1016/j.ypmed.2013.05.012.

19. Potestio M, Patel A, Powell C, McNeil D, Jacobson RD, McLaren L. Is there an association between spatial access to parks/green space and childhood overweight/obesity in Calgary, Canada? Int J Behav Nutr Phys Act. 2009;6(1):77. http://dx.doi.org/10.1186/1479-5868-6-77.

20. Tilt JH, Unfried TM, Roca B. Using objective and subjective measures of neighborhood greenness and accessible destinations for understanding walking trips and BMI in Seattle, Washington. Am J Health Promot. 2007;21(4 Suppl):371-379. http://dx.doi.org/10.4278/0890-1171-21.4s.371.

21. Ellaway A, Macintyre S, Bonnefoy X. Graffiti, greenery, and obesity in adults: secondary analysis of European cross sectional survey. Br Med J. 2005;331:611-612. http://dx.doi.org/10.1136/bmj.38575.664549.F7. 
22. Richardson EA, Mitchell R, Hartig T, de Vries S, Astell-Burt T, Frumkin H. Green cities and health: a question of scale? J Epidemiol Community Health. 2012;66(2):160-165. http://dx.doi.org/10.1136/jech.2011.137240.

23. Niemela J, Saarela SR, Soderman T, et al. Using the ecosystem services approach for better planning and conservation of urban green spaces: a Finland case study. Biodivers Conserv. 2010;19(11):3225-3243. http://dx.doi.org/10.1007/s10531-010-9888-8.

24. Tzoulas K, Korpela K, Venn S, Yli-Pelkonen V, Kazmierczak A, Niemela J, et al. Promoting ecosystem and human health in urban areas using Green Infrastructure: A literature review. Landsc Urban Plan. 2007;81(3):167-178. http://dx.doi.org/10.1016/j.landurbplan.2007.02.001.

25. Carinanos P, Casares-Porcel M. Urban green zones and related pollen allergy: A review. Some guidelines for designing spaces with low allergy impact. Landsc Urban Plan. 2011;101(3):205-214. http://dx.doi.org/10.1016/j.landurbplan.2011.03.006.

26. Jongman RHG, Külvik M, Kristiansen I. European ecological networks and greenways. Landsc Urban Plan. 2004;68(2-3):305-319. http://dx.doi.org/10.1016/S01692046(03)00163-4.

27. Schipperijn J, Stigsdotter UK, Randrup TB, Troelsen J. Influences on the use of urban green space - A case study in Odense, Denmark. Urban Forestry \& Urban Greening. 2010;9(1):25-32. http://dx.doi.org/10.1016/j.ufug.2009.09.002.

28. Birch TW, Hershey RR, Kern P. Identifying forest lands in urban areas in the Central Hardwood Region. In: Pallardy SG, Cecich RA, Garrett HG, Johnson PS, editors. 11th Central Hardwood Forest Conference, Proceedings. St Paul: U.S. Dept Agr, Forest Serv, N Cent Res Stn; 1997. p. 98-116. 
29. Di Giulio M, Holderegger R, Tobias S. Effects of habitat and landscape fragmentation on humans and biodiversity in densely populated landscapes. J Environ Manage. 2009;90(10):2959-2968. http://dx.doi.org/10.1016/j.jenvman.2009.05.002.

30. Fahrig L. Effects of habitat fragmentation on biodiversity. Annu Rev Ecol Evol Syst. 2003;34:487-515. http://dx.doi.org/10.1146/annurev.ecolsys.34.011802.132419.

31. Le Tortorec E, Helle S, Käyhkö N, Suorsa P, Huhta E, Hakkarainen H. Habitat fragmentation and reproductive success: a structural equation modelling approach. $J$ Anim Ecol. 2013;82(5):1087-1097. http://dx.doi.org/10.1111/1365-2656.12075.

32. Murcia C. Edge effects in fragmented forests: implications for conservation. Trends Ecol Evol. 1995;10(2):58-62. http://dx.doi.org/10.1016/S0169-5347(00)88977-6.

33. Peyras M, Vespa NI, Bellocq MI, Zurita GA. Quantifying edge effects: the role of habitat contrast and species specialization. J Insect Conserv. 2013;17(4):807-820. http://dx.doi.org/10.1007/s10841-013-9563-y.

34. Ewing R, Schmid T, Killingsworth R, Zlot A, Raudenbush S. Relationship between urban sprawl and physical activity, obesity, and morbidity. Am J Health Promot. 2003;18(1):47-57. http://dx.doi.org/10.4278/0890-1171-18.1.47.

35. U.S. Census Bureau. Geographic areas reference manual - Chapter 13: Metropolitan areas. 2010.

36. Fry J, Xian G, Jin S, et al. Completion of the 2006 National Land Cover Database for the conterminous United States. Photogramm Eng Remote Sensing. 2011;77(9):858-864.

37. Wen M, Zhang X, Harris CD, Holt JB, Croft JB. Spatial disparities in the distribution of parks and green spaces in the USA. Ann Behav Med. 2013;45(Suppl 1):S18-27. http://dx.doi.org/10.1007/s12160-012-9426-x. 
38. Wickham JD, Stehman SV, Gass L, Dewitz J, Fry JA, Wade TG. Accuracy assessment of NLCD 2006 land cover and impervious surface. Remote Sens Environ. 2013;130(0):294304. http://dx.doi.org/10.1016/j.rse.2012.12.001.

39. Wu J, Hobbs R. Key topics in landscape ecology. Cambridge: Cambridge University Press; 2007. http://dx.doi.org/10.1017/CBO9780511618581.

40. Wu J, Shen W, Sun W, Tueller P. Empirical patterns of the effects of changing scale on landscape metrics. Landsc Ecol. 2002;17(8):761-782. http://dx.doi.org/10.1023/A:1022995922992.

41. Arnberger A. Recreation use of urban forests: An inter-area comparison. Urban Forestry \& Urban Greening. 2006;4(3-4):135-144. http://dx.doi.org/10.1016/j.ufug.2006.01.004.

42. Brownson RC, Chriqui JF, Stamatakis KA. Understanding evidence-based public health policy. Am J Public Health. 2009;99(9):1576-1583. http://dx.doi.org/10.2105/AJPH.2008.156224.

43. Forsyth A, Musacchio L. Designing small parks: a manual addressing social and ecological concerns. Hoboken, NJ: Wiley; 2005.

44. Ruddell EJ, Hammitt WE. Prospect refuge theory: a psychological orientation for edge effects in recreation environment. J Leis Res. 1987;19(4):249-260.

45. Mcgarigal K. FRAGSTATS v4 Help: Spatial pattern analysis program for categorical and continuous maps. 2012; www.umass.edu/landeco/research/fragstats/documents/fragstats.help.4.2.pdf.

46. Braveman PA, Cubbin C, Egerter S, Williams DR, Pamuk E. Socioeconomic disparities in health in the United States: what the patterns tell us. Am J Public Health. 2010;100(Suppl 1):S186-196. http://dx.doi.org/10.2105/AJPH.2009.166082. 
47. Frank LD, Schmid TL, Sallis JF, Chapman J, Saelens BE. Linking objectively measured physical activity with objectively measured urban form: findings from SMARTRAQ. Am J Prev Med. 2005;28(2 Suppl 2):117-125. http://dx.doi.org/10.1016/j.amepre.2004.11.001.

48. Ewing R, Brownson RC, Berrigan D. Relationship between urban sprawl and weight of United States youth. Am J Prev Med. 2006;31(6):464-474. http://dx.doi.org/10.1016/j.amepre.2006.08.020.

49. Cavanaugh JE. Akaike information criterion. Encyclopedia of measurement and statistics. SAGE Publications, Inc. Thousand Oaks, CA: SAGE Publications, Inc.; 2007.

50. Hox JJ. Hierarchical regression models for interviewer and respondent effects. Sociol Methods Res. 1994;22(3):300-318. http://dx.doi.org/10.1177/0049124194022003002.

51. Maas J, Verheij R, Spreeuwenberg P, Groenewegen P. Physical activity as a possible mechanism behind the relationship between green space and health: A multilevel analysis. BMC Public Health. 2008;8(1):206. http://dx.doi.org/10.1186/1471-2458-8-206.

52. Toftager M, Ekholm O, Schipperijn J, et al. Distance to green space and physical activity: a Danish national representative survey. J Phys Act Health. 2011;8(6):741-749.

53. Giles-Corti B, Broomhall MH, Knuiman M, et al. Increasing walking: How important is distance to, attractiveness, and size of public open space? Am J Prev Med. 2005;28(2 Suppl 2):169-176. http://dx.doi.org/10.1016/j.amepre.2004.10.018.

54. Kaczynski AT, Potwarka LR, Saelens BE. Association of park size, distance, and features with physical activity in neighborhood parks. Am J Public Health. 2008;98(8):14511456. http://dx.doi.org/10.2105/AJPH.2007.129064. 
55. Tamosiunas A, Grazuleviciene R, Luksiene D, et al. Accessibility and use of urban green spaces, and cardiovascular health: findings from a Kaunas cohort study. Environ Health. 2014;13(1):20. http://dx.doi.org/10.1186/1476-069X-13-20.

56. Hillsdon M, Panter J, Foster C, Jones A. The relationship between access and quality of urban green space with population physical activity. Public Health. 2006;120(12):11271132. http://dx.doi.org/10.1016/j.puhe.2006.10.007.

57. Maas J, Verheij R, Groenewegen P, de Vries S, Spreeuwenberg P. Green space, urbanity and health: how strong is the relation? J Epidemiol Community Health. 2006;60:587-592. http://dx.doi.org/10.1136/jech.2005.043125.

58. Rand TA, Tylianakis JM, Tscharntke T. Spillover edge effects: the dispersal of agriculturally subsidized insect natural enemies into adjacent natural habitats. Ecol Lett. 2006;9(5):603-614. http://dx.doi.org/10.1111/j.1461-0248.2006.00911.x.

59. Edwards D, Jay M, Jensen FS, et al. Public preferences for structural attributes of forests: Towards a pan-European perspective. Forest Policy Econ. 2012;19(0):12-19. http://dx.doi.org/10.1016/j.forpol.2011.07.006.

60. Kaplan R. With people in mind: design and management of everyday nature. Washington, D.C.: Island Press; 1998.

61. Mumcu S, Düzenli T, Özbilen A. Prospect and refuge as the predictors of preferences for seating areas. Sci Res Essays. 2010;5(11):1223-1233.

62. Shanahan DF, Fuller RA, Bush R, Lin BB, Gaston KJ. The Health Benefits of Urban Nature: How Much Do We Need? BioScience. 2015;65(5):476-485. http://dx.doi.org/10.1093/biosci/biv032. 
63. Roberts JD, Voss JD, Knight B. The association of ambient air pollution and physical inactivity in the United States. Plos One. 2014;9(3):e90143. http://dx.doi.org/10.1371/journal.pone.0090143.

64. Yore M, Ham S, Ainsworth B, et al. Reliability and validity of the instrument used in BRFSS to assess physical activity. Med Sci Sports Exerc. 2007;39:1267-1274. http://dx.doi.org/10.1249/mss.0b013e3180618bbe.

65. Pierannunzi C, Hu SS, Balluz L. A systematic review of publications assessing reliability and validity of the Behavioral Risk Factor Surveillance System (BRFSS), 2004-2011. BMC Med Res Methodol. 2013;13(1):49. http://dx.doi.org/10.1186/1471-2288-13-49.

66. Bolleter J, Ramalho CE. The potential of ecologically enhanced urban parks to encourage and catalyze densification in greyfield suburbs. J Landsc Archit. 2014;9(3):54-65. http://dx.doi.org/10.1080/18626033.2015.968418.

67. Wickham JD, Riitters KH, Wade TG, Vogt P. A national assessment of green infrastructure and change for the conterminous United States using morphological image processing. Landsc Urban Plan. 2010;94(3-4):186-195. http://dx.doi.org/10.1016/j.landurbplan.2009.10.003.

68. Opdam P, Steingröver E, Rooij Sv. Ecological networks: A spatial concept for multiactor planning of sustainable landscapes. Landsc Urban Plan. 2006;75(3-4):322-332. http://dx.doi.org/10.1016/j.landurbplan.2005.02.015. 


\section{List of Figures}

Figure 1. Study area.

Note: Metropolitan statistical areas with population over one million were selected $(\mathrm{N}=52)$.

These 52 MSAs comprised 421 counties, however, only 135 counties were included in this study due to data limitation. 
Table 1. Selected Fragmentation Metrics in This Study

\begin{tabular}{|c|c|c|c|}
\hline Domain & Metrics & Unit & Description \\
\hline \multirow{2}{*}{$\begin{array}{l}\text { Area-Edge: } \\
\text { Measure } \\
\text { landscape } \\
\text { composition } \\
\text { and the } \\
\text { simplest } \\
\text { configuration }\end{array}$} & $\begin{array}{l}\text { Percentage of } \\
\text { land cover } \\
(\%)\end{array}$ & $\%$ & $\begin{array}{l}\text { The proportional abundance of each patch type in } \\
\text { the landscape }\end{array}$ \\
\hline & $\begin{array}{l}\text { Patch area } \\
\text { (AREA) }\end{array}$ & $\mathrm{m}^{2}$ & $\begin{array}{l}\text { Mean of the total area of the corresponding patch } \\
\text { type }\end{array}$ \\
\hline \multirow[b]{2}{*}{$\begin{array}{l}\text { Contrast: } \\
\text { Measure the } \\
\text { relative } \\
\text { difference } \\
\text { among patch } \\
\text { types }\end{array}$} & $\begin{array}{l}\text { Edge density } \\
\text { (ED) }\end{array}$ & $\mathrm{m} / \mathrm{ha}$ & $\begin{array}{l}\text { The sum of the lengths of all edge segments } \\
\text { involving the corresponding patch type in an area }\end{array}$ \\
\hline & $\begin{array}{l}\text { Edge contrast } \\
\text { index } \\
(\mathrm{ECON})\end{array}$ & $\%$ & $\begin{array}{l}\text { The sum of the patch perimeter segment lengths } \\
\text { multiplied by their corresponding contrast weights } \\
\text { (i.e., developed area and forest, shrubland, or } \\
\text { herbaceous types were weighted by } 1 \text {, and all others } \\
\text { were weighted by } 0 \text { in this study) divided by total } \\
\text { patch perimeter }\end{array}$ \\
\hline \multirow{3}{*}{$\begin{array}{l}\text { Aggregation: } \\
\text { Measure the } \\
\text { degree of } \\
\text { aggregation } \\
\text { or clumping of } \\
\text { patch types }\end{array}$} & $\begin{array}{l}\text { Patch density } \\
\text { (PD) }\end{array}$ & \#/100ha & $\begin{array}{l}\text { The number of patches of the corresponding patch } \\
\text { type per } 100 \text { hectares }\end{array}$ \\
\hline & $\begin{array}{l}\text { Euclidean } \\
\text { distance } \\
\text { (ENN) }\end{array}$ & $\mathrm{m}$ & $\begin{array}{l}\text { ENN equals the distance }(\mathrm{m}) \text { to the nearest } \\
\text { neighboring patch of the same type, based on } \\
\text { shortest edge-to-edge distance. }\end{array}$ \\
\hline & $\begin{array}{l}\text { Patch } \\
\text { cohesion } \\
\text { index } \\
(\mathrm{COHESION})\end{array}$ & $\%$ & $\begin{array}{l}\text { The physical connectedness of the corresponding } \\
\text { patch type measured by its perimeter, total area, and } \\
\text { number of patches }\end{array}$ \\
\hline
\end{tabular}


Table 2. Significant Bivariate Relationships of Vegetative Cover Characteristics With Physical Activity

\begin{tabular}{|c|c|c|c|c|c|}
\hline \multicolumn{6}{|c|}{ Physical activity } \\
\hline Metric & rho & Metric & rho & Metric & rho \\
\hline$\%$ Forest & $0.257 * *$ & \% Shrubland & $0.215 *$ & \%Herbaceous & $0.327 * * *$ \\
\hline Forest_AREA & $0.202 * *$ & Shrubland_PD & $0.263 * *$ & Herbaceous_PD & $0.350 * * *$ \\
\hline Forest_ED & $0.253 * *$ & Shrubland_ED & $0.239 * *$ & Herbaceous_ED & $0.339 * * *$ \\
\hline Forest_ENN & $-0.216^{*}$ & Shrubland_ECON & $-0.206 *$ & Herbaceous_ECON & $-0.213^{*}$ \\
\hline Forest_COHESION & $0.232 * *$ & & & Herbaceous_ENN & $-0.250 * *$ \\
\hline
\end{tabular}

Note: Boldface indicates statistical significance $(* p<0.05 ; * * p<0.01 ; * * * p<0.001)$.

There is no significant bivariate relationships between vegetative characteristics and normal BMI.

$\%$ is percentage of land cover $(\%)$; AREA is averaged patch area $\left(\mathrm{m}^{2}\right)$; PD is patch density (\#/100ha); ED is edge density (m/ha);

ECON is edge contrast index $(\%)$; ENN is Euclidean distance $(\mathrm{m})$; and COHESION is patch cohesion index $(\%)$. 
Table 3. Multivariate Relationships of Vegetative Cover Characteristics With Physical Activity and Normal BMI

\begin{tabular}{|c|c|c|c|c|c|c|c|c|c|c|}
\hline \multirow[b]{3}{*}{ Variables } & \multicolumn{5}{|c|}{ Physical activity } & \multicolumn{5}{|c|}{ Normal BMI } \\
\hline & \multirow{2}{*}{$\begin{array}{c}\begin{array}{c}\text { Unstandardized } \\
\text { coefficients }\end{array} \\
\text { B }\end{array}$} & \multirow{2}{*}{$\begin{array}{c}\begin{array}{c}\text { Standardized } \\
\text { coefficients }\end{array} \\
\text { Beta }\end{array}$} & \multirow{2}{*}{ VIF } & \multicolumn{2}{|c|}{$95 \% \mathrm{CI}$ for $\mathrm{B}$} & \multirow{2}{*}{$\begin{array}{c}\begin{array}{c}\text { Unstandardized } \\
\text { coefficients }\end{array} \\
\text { B }\end{array}$} & \multirow{2}{*}{$\begin{array}{c}\begin{array}{c}\text { Standardized } \\
\text { coefficients }\end{array} \\
\text { Beta }\end{array}$} & \multirow{2}{*}{ VIF } & \multicolumn{2}{|c|}{$95 \% \mathrm{CI}$ for $\mathrm{B}$} \\
\hline & & & & $\begin{array}{l}\text { Lower } \\
\text { Bound }\end{array}$ & $\begin{array}{l}\text { Upper } \\
\text { Bound }\end{array}$ & & & & $\begin{array}{l}\text { Lower } \\
\text { Bound }\end{array}$ & $\begin{array}{l}\text { Upper } \\
\text { Bound }\end{array}$ \\
\hline$\%$ Forest & $D L$ & $D L$ & $D L$ & $D L$ & $D L$ & $6.54 \mathrm{E}-02$ & 0.225 & 3.76 & $-1.44 \mathrm{E}-02$ & $1.45 \mathrm{E}-01$ \\
\hline Forest_AREA & $5.52 \mathrm{E}-03$ & 0.022 & 1.52 & $-3.87 \mathrm{E}-02$ & 4.98E-02 & $N S$ & $N S$ & $N S$ & $N S$ & $N S$ \\
\hline Forest_ED & $5.20 \mathrm{E}-02 *$ & 0.272* & 2.59 & 8.86E-03 & 9.52E-02 & $-4.57 \mathrm{E}-02$ & -0.221 & 5.52 & $-1.15 \mathrm{E}-01$ & $2.31 \mathrm{E}-02$ \\
\hline Forest_ECON & $N S$ & $N S$ & $N S$ & $N S$ & $N S$ & 8.03E-02** & $0.370 * *$ & 2.45 & $3.21 \mathrm{E}-02$ & 1.28E-01 \\
\hline Shrubland_AREA & $N S$ & $N S$ & $N S$ & $N S$ & $N S$ & $-3.64 \mathrm{E}-03$ & -0.030 & 1.51 & $-2.48 \mathrm{E}-02$ & $1.75 \mathrm{E}-02$ \\
\hline Shrubland_PD & $-1.33 \mathrm{E}+00$ & -0.291 & 4.68 & $-2.72 \mathrm{E}+00$ & $5.94 \mathrm{E}-02$ & $-2.49 \mathrm{E}+00 * *$ & $-0.504 * *$ & 4.97 & $-4.05 \mathrm{E}+00$ & $-9.29 \mathrm{E}-01$ \\
\hline Shrubland_ED & 7.91E-02 & 0.287 & 4.91 & $-6.51 \mathrm{E}-03$ & $1.65 \mathrm{E}-01$ & $1.92 \mathbf{E}-01 * * *$ & $0.646 * * *$ & 5.35 & $9.47 \mathrm{E}-02$ & 2.90E-01 \\
\hline Shrubland_ENN & $-1.94 \mathrm{E}-04$ & -0.053 & 1.34 & $-7.93 \mathrm{E}-04$ & 4.04E-04 & $N S$ & $N S$ & $N S$ & $N S$ & $N S$ \\
\hline Herbaceous_AREA & 2.31E-01** & $0.261 * *$ & 1.85 & 6.20E-02 & 3.99E-01 & 3.18E-01** & $0.332 * *$ & 1.94 & 1.29E-01 & 5.07E-01 \\
\hline Herbaceous_ENN & $-1.13 \mathrm{E}-03$ & -0.150 & 1.41 & $-2.38 \mathrm{E}-03$ & $1.26 \mathrm{E}-04$ & $-1.05 \mathrm{E}-03$ & -0.129 & 1.32 & $-2.38 \mathrm{E}-03$ & 2.79E-04 \\
\hline Herbaceous_COHESION & $-3.88 \mathrm{E}-02$ & -0.066 & 3.09 & $-1.84 \mathrm{E}-01$ & $1.07 \mathrm{E}-01$ & $-1.80 \mathrm{E}-01 *$ & $-0.281 *$ & 3.08 & $-3.38 \mathrm{E}-01$ & $-2.05 E-02$ \\
\hline Population density & $D L$ & $D L$ & $D L$ & $D L$ & $D L$ & $D L$ & $D L$ & $D L$ & $D L$ & $D L$ \\
\hline Housing density & 2.69E-04 & 0.037 & 1.38 & $-9.22 \mathrm{E}-04$ & $1.46 \mathrm{E}-03$ & $1.31 \mathrm{E}-03$ & 0.167 & 1.64 & $-1.14 \mathrm{E}-04$ & $2.73 \mathrm{E}-03$ \\
\hline Median household income & $1.28 \mathrm{E}-04 * * *$ & $0.415 * * *$ & 1.67 & $7.20 \mathrm{E}-05$ & 1.83E-04 & 8.72E-05** & $0.262 * *$ & 1.56 & 2.84E-05 & 1.46E-04 \\
\hline Race & $-3.15 \mathrm{E}-02$ & -0.087 & 1.72 & $-9.83 \mathrm{E}-02$ & $3.53 \mathrm{E}-02$ & $-9.29 \mathrm{E}-02 *$ & $-0.237 *$ & 1.78 & $-1.67 E-01$ & $-1.88 \mathrm{E}-02$ \\
\hline Adjusted $\mathbf{R}^{2}$ & 0.353 & & & & & 0.335 & & & & \\
\hline
\end{tabular}

Note: Boldface indicates statistical significance $(* p<0.05 ; * * p<0.01 ; * * * p<0.001)$.

VIF, Variance Inflation Factor; DL, Deleted from final selected model due to high VIF ( $>10)$; NS, Not selected into model.

$\%$ is percentage of land cover (\%); AREA is averaged patch area $\left(\mathrm{m}^{2}\right)$; PD is patch density (\#/100ha); ED is edge density (m/ha); ECON is edge contrast index (\%); ENN is Euclidean distance (m); and COHESION is patch cohesion index $(\%)$ 


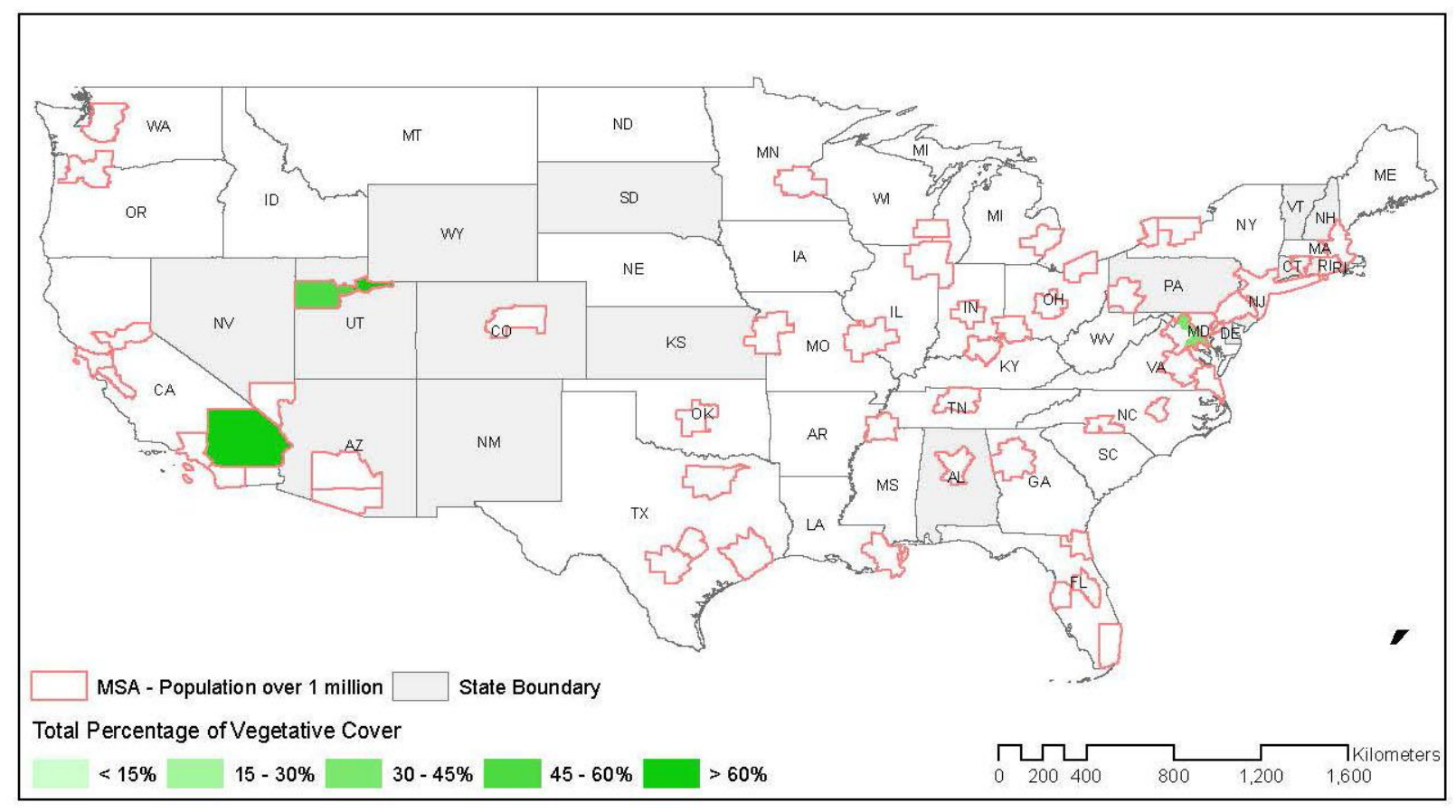

